\title{
Empirical Analysis of Corporate Sustainability Performance: Linkage of Japanese Firms' Environmental and Economic Performance
}

\author{
K. Gnanaweera \\ Toyama Prefectural University, Japan
}

\section{N. Kunori}

Women's University, Japan

\begin{abstract}
The linkage between Corporate Environmental Performance (CEP) and Corporate Financial Performance (CFP) has been a long-standing debate since all previous efforts achieved inconsistent results. The current study therefore attempts to present the relationship between corporations' environmental and financial performance to explore the notion of Corporate Social Responsibility (CSR) in a developed nation. This case derives empirical observational data from corporate sustainability reports and integrated annual reports of Japanese firms. The sample is comprised of observational data of a total of 85 Japanese corporations from 2008 to 2014. The selected firms are listed on the Tokyo Stock Exchange in the first section of the market division and are categorized under various industrial sectors. The effort of the current study has revealed that corporate environmental measurements have different effects on financial performance. The evidence was less strong in evaluating the impact level of all variables except firm size (total assets). Three hypotheses $\left(\mathrm{H}_{1}, \mathrm{H}_{2}\right.$, and
\end{abstract}

\section{Corresponding Author:}

Mr. K. Gnanaweera is a PhD candidate at the Department of Environmental Engineering, Toyama Prefectural University, Japan. E-mail: kamakg7@gmail.com 
$\mathrm{H}_{3}$ ) were developed for further evaluation of the effect of financial indicators on environmental performance. $H_{1}$ was accepted since environmental performance has a significant impact on firm size. However, the rejected $\mathrm{H}_{2}$ and $\mathrm{H}_{3}$ state that environmental performance has no significant impact on financial leverage and profitability, due to the weak relationship or insignificant outcome, i.e. in the profitability measurement, only Return on Sales (ROS) showed positive correlation between particular $C E P$ variables, but the coefficient of determination $\left(R^{2}\right.$ value $)$ does not support the ROS contribution for every model in the study. The other two profitability ratios (return on assets and return on equity) have less contribution. Both the relationship between environmental performance and financial performance according to $R^{2}$ values and the relationship between $C E P$ and CFP are broad spectrums that yet to be explored.

\section{Keywords}

Corporate, Environmental, Financial, Sustainability, Tokyo Stock Exchange

\section{Introduction}

Corporations are rapidly growing their businesses to trade their products and services worldwide. In his classic book, The Concept of the Corporation, Peter F. Drucker (1946), founder of the Modern Management Theory, explains that Management has become a major leadership group in the industrial society and as such have great responsibilities to their enterprise and to the people they manage, and to their economy and society.

Corporate Social Responsibility (CSR) is to be approached by academics, consultants, policy makers, practitioners, and scholars as a contemporary business function of responsible businesses. At the beginning of the 20th century, CSR was observed as a base point for compatible and responsible business ventures. A long-standing debate on CSR has been taking place since the second half of the 20th century (Garriga \& Mele, 2004). The Oxford Handbook of Corporate Social Responsibility explains that CSR has taken a journey that is almost unique in the pantheon of ideas in management literature (Crane, Matten, McWilliams, Moon, \& Siegel, 2008). While gaining acceptance in the 20th century, the concepts of CSR have gained different exposures and descriptions. It is even known by different names by scholars and institutions; social responsibility, corporate 
social performance, corporate citizenship, sustainable business responsibility, corporate sustainability, etc. In addition, Garriga and Mele (2004) clarified that CSR has grown up significantly but has propagated some excessive theories, alignments, and terminologies. They even explored certain terms and descriptions related to CSR such as, society in business, social issues management, public policy and private partnership, stakeholder management, and corporate accountability. However, in addition to having many different titles, there is also no standard definition for CSR. As a result, different perspectives of CSR models are being guided by scholars and standard-setting groups to advance their own principles.

Numerous studies have investigated corporate businesses and the role they play in environmental disputes. CSR evaluation standards have been constructed based mainly on the performance of a company. Corporations have focused on improving their environmental performance while pursuing maximum financial return, and based on the works of many academics, this has been an aspect explored extensively (Carroll, 1979; Christamann, 2000; Dowell, Hart, \& Yeung, 2000; Feldman, Soyka, \& Ameer, 1997; Hart \& Ahuja, 1996; Orlitzky, Schmidt, \& Rynes, 2003; Waddock \& Graves, 1997). The results of these studies produced mixed outcomes; however, it is essential to articulate the particular research area since sustainability performance should synchronize Corporate Financial Performance (CFP) and Corporate Environmental Performance (CEP), which are aspects of particular concern in the study of sustainability management. Schaltegger and Synnestvedt (2002) claimed that there are several reasons that strengthen these different views on the relationship between environmental performance and economic success. They further determined that the performance disparity may have been caused due to economic disincentives for corporate environmental protection, focus on short term profit, or even pure ignorance. Orlitzky (2008) also explained that environmental performance is not typically considered an investment, but is treated as a cost instead, thus regarding it as insignificant in terms of its problematic nature. Nevertheless, environmental management is a major obligation from a global perspective, even though consumers and shareholders are not as concerned about the organization's environmental performance as they are about the company's products or stock value. These causes produce conflicting consequences within the corporate sustainability criteria. 
Therefore, based on their evidence on these consequences, many researchers have tried to provide answers, however the outcomes remain varied.

Further, the analysis includes prior studies linking environmental performance and financial performance specifically related to western regions (Hart \& Ahuja, 1996; Christamann, 2000; Dowell et al., 2000; Konar \& Cohen, 2001). Therefore, it is vital to pursue further analysis for Non-western regions, especially industrialized nations since the argument of industrialization's global impact cannot just be restricted to Western regions. Brouwers, Schoubben, Van Hulle and Van Uytbergen (2014) found the Asian region to be accountable for nearly half of the world's carbon emission, therefore it is important that this discussion considers the impact level of the environmental obligation on firm performance in this region. Brouwers et al. (2014) argued that environmental performance studies of Asian firms scarcely exist; therefore, the practical implications and originality of this study will be elaborated as a case study of Japanese corporations' CSR approaches. These statements designate what this study was set off to explore; the main objective of this study is to investigate if Japanese corporate sustainability and responsibility exhibits a significant relationship between its CEP and CFP. This study assesses the correlation between environmental performance indicators and the financial performance indicators of firms based on a data set of Japanese corporations listed on the Tokyo Stock Exchange (TSE), in the first section of the market division from 2008 to 2014. Japan is the first nation to equal the West in transforming itself into an industrial society and this relationship to the Japanese business environment is a reliable source to understand its implications. Therefore, the context of this study is original. The progression of this study aims to assess in a quantitative manner, so as to contribute to the growing research information on the subject of CSR and sustainability management. Research on sustainability with quantifying CSR observations is in a phase of development that is rapidly growing. As a result, this study based on empirical evidence strives to provide answers to the following Research Question (RQ).

RQ: Is there any correlation between a firm's environmental performance and financial performance allied to Asian firms in a developed nation? 
To address these research objectives, the remainder of the paper is organized as follows. Section two reviews the existent literature on CSR concepts, sustainability management, Japanese CSR, and correlations between CEP and CFP. Section three explains the methodology, while section four presents the analysis and its results. Based on the research findings, section five discusses their implications and the conclusions.

\section{Literature Review}

CSR, also called corporate conscience, corporate citizenship, social performance, or sustainable responsible business, is a form of corporate self-regulation integrated into the business model (Fontaine, 2013). According to eminent CSR author, professor emeritus Archie B. Carroll (1979), CSR began in the 1950s; however, he considers certain developments that took place before that time, such as activities and practices originating in the industrial revolution: may be a useful starting point. Carroll (1979) contended that the modern era of social responsibility may be marked by Howard R. Bowen's (1953) publication of Social Responsibility of the Businessman. Furthermore, Carroll (1979) recognized Bowen as the father of CSR because Bowen's book was considered the first definitive book on the subject. Other academics published a number of studies on this same stream of thought followed by Bowen's book; Cheit (1964), Davis (1960), Davis and Blomstrom (1966), Greenwood (1964), Mason (1960), and McGuire (1963). After Carroll (1979), Smith (2011) understood the concept of CSR to have started in the 1920s, although it failed to become a serious topic among business leaders until the 1950s due to the Great Depression and World War II. Smith (2011) stated that interest in CSR increased after Frank Abrams, in 1951, suggested it to be an obligation of business.

The concept of CSR is not new; it has been an ongoing debate among academics, the public, corporations, politicians, and society. What is CSR, how is it defined by scholars within their context? If firms are to be socially responsible, then who is responsible to whom? Mele (2008) recognized that identifying the great variety of existing approaches to CSR is challenging. Furthermore, Mele (2008) identified that a certain limited vision of a philosophical framework is inclusive on those theories. Klonoski (1991) distinguished three kinds of CSR theories. The first classification is 
contradicted by social philosophy; however, a group of fundamentalists believe that corporations' only social responsibility is increasing profits while complying with the law. The second classification propounds corporations' moral personhood whilst the third is rooted in politics and ethics. It is difficult to find the proper dimensions of a theoretical framework underlying the theories of CSR. Carroll (1979) came up with his own definition of social responsibility to give a more wholesome response on the entire range of business obligations for society; it must embody the economic, legal, ethical, and discretionary categories of business performance. Carroll's Three-Dimensional Conceptual Model (1979) can be used to conceptualize the key issues in social performance. Cannon (1992) stated that the primary role of a business was to produce goods and services that the society needs and wants, however there was a sense of interdependence between the business and society due to the need of a stable environment. The basic idea of CSR according to Wood (1991) is that businesses and the society are interwoven, rather than being distinct entities.

Some have argued that a business exists because society allows it to exist by its support; therefore, businesses are obligated to repay society for the profit it makes. Ivancevich, Lorenzi, Skinner and Crosby (1997) described CSR as a social obligation; and therefore, corporations must behave in a socially responsible way as they pursue profits within the boundaries of the law. Economics Nobel Prize winner Milton Friedman (1970) stated that the society creates firms to follow two primary drives; to produce goods and services efficiently, and to maximize profits. According to Carroll's Three-Dimensional Conceptual Model of Corporate Performance (1979), two classes are missing in Friedman's option; ethical responsibilities and discretionary responsibilities. As Carroll (1979) explained, these two classes are the most difficult for a business to deal with, due to their level of ambiguity. It is difficult for businesses to identify what is and is not ethical, and its discretionary role is purely voluntary.

\section{Linkage of Environmental Performance and Financial Performance}

According to the Ministry of Environment, Japan (MOE) (https://www.env.go.jp/en/) and the Global Reporting Initiative (2013), environmental performance is a prominent domain in CSR disclosures since it is a moderating variable in analyzing the influence of a business's 
sustainability. Therefore, environmental performance indicators are another dimension of measuring the influence of CSR within a company. A company's financial performance indicators and returns on equity, assets, and sales are also the important domains that indicate the linkage of shareholders and stakeholders when evaluating the influence of CSR within a company. Over the last three decades, a considerable number of empirical studies have endeavored to establish a link between these two domains of companies to analyze corporate sustainability and evaluate responsible businesses (Aupperle, Carroll, \& Hatfield, 1985; Iwata \& Okada, 2011; Schaltegger \& Synnestvedt, 2002). The proper balance of environmental performance and financial performance within an organization is a subject of unending debate; and researchers have considered alternate and moderated theories to explain this tension.

Academics (Porter \& Van der Linde, 1995; Shrivastava, 1995; Trung \& Kumar, 2005; Stefan \& Paul, 2008) have vigorously studied this matter using numerous approaches, but finding the correlation of these two factors remains a key question. Some academics suggest that high environmental performance may help organizations gain a competitive advantage if corporate environmental policies form a part of the firm's strategy (Porter, 1991; Porter \& Van der Linde, 1995; Hart \& Ahuja, 1996). According to the Neoclassical Agency Theory, the expected costs of a firm's environmental responsibility are likely to outweigh the resulting profits (Brouwers et al., 2014). However, some have argued that emphasizing environmental practices may bring forth few financial benefits (Jaffe, Peterson, Portney, \& Stavins, 1995; Walley \& Whitehead, 1994). Shrivastava and Hart (1992) argued that philosophically, pollution is a sign of inefficient operation, and waste is an irrecoverable cost for the company.

Furthermore, in the study Does it Pay to be Green, Hart and Ahuja (1996) recommend that once companies make efforts to prevent emissions, operating performance will significantly increase in the following years. Konar and Cohen (2001) evaluated the relationship between CEP and intangible assets to assess the correlation of environmental and financial aspects. In this study, two environmental performance indicators were taken into account: Toxic Release Inventory (TRI) emission levels, and pending environment-related litigation. The intangible assets the study measured 
were a firm's market value and sales growth. A 10 per cent lower TRI was found to correlate with an intangible asset value that was $\$ 34$ million larger.

Consistent with the findings of Konar and Cohen (2001), Stanwick and Stanwick (1998) also found a significant correlation between low emission levels and profitability. Feldman et al. (1997) also realized that firms with CSR policies to improve their environmental management, lower costs while lowering toxic emission. Russo and Fouts (1997) then determined that the Return of Assets (ROA) improve as environmental performance improves (Murphy, 2002). Inconsistently, Repetto and Austin (2001) found that firms in the pulp industry are more likely to be affected by environmental regulations (if implemented) and were expected to experience a decline in market value. Chemical companies are also likely to be impacted by such environmental legislation. With the exception of chemical, pulp and paper companies, Miles and Covin (2000) concluded that good environmental stewardship helps create a reputational advantage that leads to enhanced marketing and financial performance.

Empirical studies conducted on the relationship between environmental performance and financial performance of business corporations has a long history. Recent studies tend to provide increasing evidence of a positive association of the two aspects. However, historically to the present, studies have reflected mixed results regarding this relationship. A negative linkage of CEP and CFP has also been found by many academics (Judge \& Douglas, 1998; Watson, Klingenberg, Polito, \& Geurts, 2004; Hassel, Nilsson, \& Nyquist, 2005; Jacobs, Singhal, \& Subramanian, 2010). According to empirical research conducted on the relationship between environmental and financial performance, a wide variety of tests must be taken into account to have reliable outcomes. After studying 20 of the leading empirical studies, Murphy (2002) concluded that strong financial performance is positively linked with environmental performance, and that negative environmental performance leads to negative results. In relation to this study, Murphy's study (2002) demonstrated that the ROA and Return on Equity (ROE) were key financial accounting measures that were to be improved when improving environmental performance. Therefore, it is vital to understand that, essentially, a company's business model should be socially responsible and environmentally sustainable. 


\section{Japanese Corporate Social Responsibility and Corporate Environmental Performance}

CSR has become important, and it has already been applied to a variety of corporations in most industrial and less-industrial regions. Japan is an industrial region, representing the third largest economy in the world, following the USA and China. Japan was the first industrialized nation in a non-western region, and it therefore has a peculiar history. CSR is both new and old in Japan; in other words, the concept of CSR, an English term, has grown in Japan in recent decades (Kawamura, 2004). The Japanese evolution of CSR started in selected phases; public distrust of industrial pollution triggers grew in the 1960's while post-oil shock corporate profiteering was censured in the 1970's. In the 1980's, corporate citizens engaged in philanthropy due to the bubble; and in the 1990's, the bubble ruined corporate ethics paving way for a rise in global environmental issues. Yamada (2006) pointed that the Japanese understanding of CSR is linked with the country's history of industrial pollution and, resulting thereof, the emergence of the Japanese environmental movement and the formation of environmental Civil Society Organizations (CSOs). The most common barriers seen in Japanese and Western contexts are those relating to policy (lack of commitment by higher levels of government), information (lack of fundamental information and data), finance (lack of fund allocations), and planning or strategy (failure to incorporate sustainability in corporate vision and policies). In addition to these common barriers, the Japanese environ brings about a number of other significant barriers as well: language, cultural communication constraints against open dialog, and less partnership development of non-government organizations than in the West are some of them. However, the typical Japanese corporate cultural characteristics that are unique to Japan, help to increase sustainability. These characteristics include the willingness to follow others, strong loyalty, hesitation to publish sustainability achievements, and an emphasis on teamwork.

Today, Japan has been widely open and recognized as a one of the finest sustainability reporting entities. The KPMG International Survey of Corporate Responsibility Reporting (2011) showed that Japan (levels of 93 per cent in 2008) has nearly unanimous adherence today, at 99 per cent. The survey included the 100 largest companies in 34 countries identified as using revenue rankings from a recognized national source; according to this 
survey, Japan is one of the largest revenue entities. The KPMG International Survey of Corporate Responsibility Reporting (2015) demonstrated that there is a lack of consistency in carbon reporting in the world's largest companies. However, Japan's 82 per cent is one of the highest rates of reporting carbon emissions and one of the highest carbon reporting assurance rates, taking fourth place in the survey. Reporting its activities is vital for a company to achieve sustainability in the global economy. Sustainability reporting can facilitate CSR information to assess the effectiveness of businesses within the society and its contribution to the economy. However, before the advent of CSR, most organizations were bound to reveal their financial and shareholder value through annual reporting.

However, reviewing the CSR management of Japanese companies, Tanimoto (2013) realized that CSR institutionalization was developing in a rapid mode since around mid 2000. Tanimoto (2013) believed that a successful CSR management process requires the awareness of employees in all departments and that it should then be embedded as a daily management process to proactively help employees understand the importance of CSR. Still, the visibility of the CSR approach and the management process in Japan is significantly different between companies running their businesses overseas and the many companies that are domestically focused, but historically inexperienced with the stakeholders' strong demand for accountability (Tanimoto, 2013). Iwata and Okada (2011) examined the effect of the environmental and financial performance of Japanese companies. The sample involved 268 Japanese manufacturing companies from 2004 to 2008. The results showed different effects of correlation between indicators, e.g., greenhouse gas reduction affected profitability in a different manner; ROE was increased, and Return on Sales (ROS) was unaffected. Furthermore, Nagayama and Takeda (2007) demonstrated a positive relationship between environmental and financial performance for 278 listed corporations in Japan from 1999-2003. Aggarwal (2013a) believed that a majority of studies observed, including that of Nakao, Amano, Matsumura, Genba and Nakano, (2007), indicated an overall positive relationship between environmental performance and financial performance. Reviewing panel data on Japanese manufacturing firms from 2010 to 2012, Nishitani and Kokubu (2014) found that if an 
improvement in productivity is considered, environmental initiatives enhance economic performance. Furthermore, Fujii, Kimbara, Kaneko and Gibson (2009) focused on how firm scale, industry type, and external pressure relate to corporate environmental management, with special reference to Japanese and US manufacturing industries. The results found that large firms are perceived to benefit more from environmental management in both regions. However, regarding the overall benefit compared to cost, Japan did not perceive significant benefits. Additionally, they found that the corporate environmental management in the Japanese region was promoted due to external pressure, particularly by government and the market.

\section{Hypotheses Development}

The above review of literature has proven that an intensive effort has been made to address CEP and corporate economic performance. In spite of this, we must continue if we are to understand whether it is possible to identify the main objective of the study, to determine whether there is a significant relationship between CEP and CFP according to Japanese corporate sustainability and responsibility. These possibilities have influenced the formulation of the following hypotheses that would determine whether there is a positive correlation between CEP and CFP. As a result, this study explored the answer for the main objective. The following hypotheses are initiated in three financial categories (firm size, financial leverage, and profitability).

Firm size vs. Environmental Performance;

$\mathbf{H}_{\mathbf{1}}$ : There is an impact of environmental performance on firm size.

Financial leverage vs. Environmental Performance;

$\mathbf{H}_{2}$ : There is an impact of environmental performance on financial leverage.

Profitability vs. Environmental Performance;

$\mathbf{H}_{3}$ : There is an impact of environmental performance on profitability.

The purpose of categorizing financial indicators is to identify the particular financial variable(s) that correlate with environmental performance of the selected firms, this would elaborate the research 
objective since the literature revealed that selected financial attributes correlate with environmental indicators, but some do not.

\section{Methodology}

The main purpose of this study is to investigate the relationship between CEP and CFP. The sample consists of 85 Japanese firms from various industrial categories (Retail Trade, Iron \& Steel; Wholesale Trade; Electric Appliances; Glass \& Ceramic Products; Chemicals; Pharmaceutical; Rubber Products; Oil \& Coal Products; Precision Instruments; Transportation Equipment; Electric Power \& Gas; Machinery; Nonferrous Metals; Marine Transportation; Construction; Information \& Communication; Metal Products; Land Transportation; Pulp \& Paper; Foods) listed on the TSK continuously from the listing date in the first section of the market division (industry classification).

The companies were randomly selected from the list of companies provided by the MOE (https://www.env.go.jp/en/), Ministry of Trade and Industry, Japan (METI) (www.meti.go.jp/english/), based on available financial and non-financial data, as per the MOEs' environmental reporting guidelines (Ministry of Environment Government of Japan, 2007) and from CSR/ sustainability/ integrated reports and other vital resources (reports, catalogs, and journals). The average of data over a period of seven years from 2008 to 2014, have been used. The study was conducted in Japan in order to sustain its validity and originality. A quantitative analysis was performed utilizing the regression analysis with IBM SPSS statistics application (version 23) to investigate the impact of CEP and CFP.

\section{Variables and the Research Model}

Analysis measurements are based on eleven major indicators related to financial and environmental variables. The following tables illustrate the variables and measurements used in the study (Table 1,2 and 3).

\section{Variables}

The independent and dependent variables used in the study are verified in Table 1. 
Table 1: Description of Variables Used in the Analysis

\begin{tabular}{lc}
\hline \multicolumn{1}{c}{ Variable } & Number of Indicators \\
\hline Dependent variable: & 6 \\
Corporate Environmental Performance (CEP) & \\
Independent variable: & 5 \\
Corporate Finance Performance (CFP) &
\end{tabular}

Source: Constructed by Authors

\section{Dependent Variables - Corporate Environmental Performance}

The Japanese MOE and METI have published guidelines on the preparation of environmental reports (Jennifer \& Taylor, 2007); according to the 2007 version of the environmental reporting guidelines, ten items need to be included in the disclosure information (Ministry of Environment Government of Japan, 2007). This information describes the status of activities carried out by the companies for environmental impact and their reduction measures; these items are known as Operational Performance Indicators (OPI). The particular CEP indicators are summarized in Figure 1 and described in Table 2.

Figure 1: Operational Performance Indicators for CEP

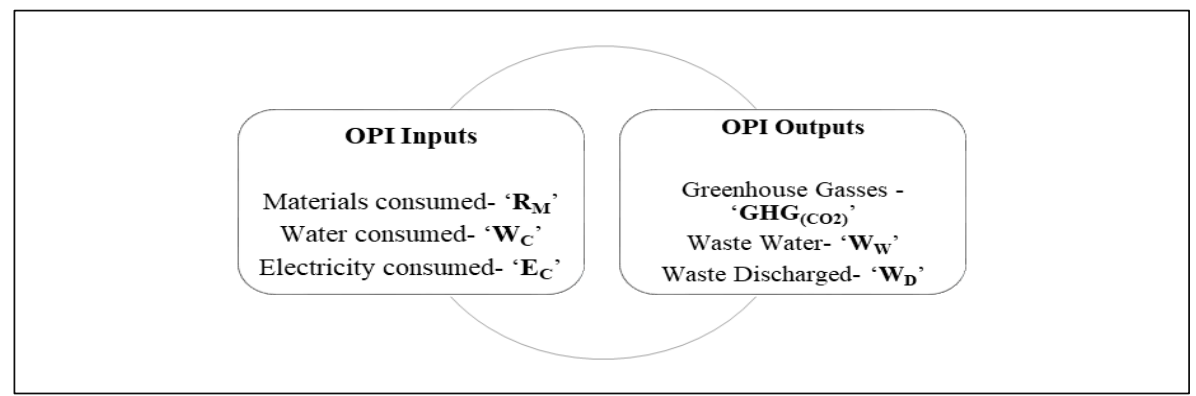

Source: Ministry of Environment Government of Japan, 2007

Table 2 presents OPI selected from ten items due to the availability of information from 2008 to 2014 from each company for analyzing.

Carbon dioxide $\left(\mathrm{CO}_{2}\right)$ is the primary anthropogenic Green House Gas (GHG). The key to financially successful emissions reduction requires an assessment of a company's strategic positioning concerning GHG emission $\left(\mathrm{CO}_{2}\right)$ (Hoffman, 2004). Evaluating the waste discharged by a firm is another main aspect of evaporating pollution to enhance environmental 
performance. The primary hazard was alleged to be Japanese industries. Discharged water was another substantial concern because the total amount of water discharge is considered to significantly impact the local community (Ministry of Environment Government of Japan, 2007). In this study, the amount of electricity consumed was preferred as an energy input.

Table 2: Description of Operational Performance Indicators

\begin{tabular}{lll}
\hline \multicolumn{1}{c}{ Variables } & Code & \multicolumn{1}{c}{ Description and Measurement } \\
\hline Greenhouse gas & $\mathrm{GHG}_{(\mathrm{CO} 2)}$ & Amount of greenhouse gas emissions; $\mathrm{CO}_{2}$ \\
Raw materials & $\mathrm{R}_{\mathrm{M}}$ & Amount of raw material input \\
Electricity consumed & $\mathrm{E}_{\mathrm{C}}$ & Amount of energy input; purchased electricity \\
Water consumed & $\mathrm{W}_{\mathrm{C}}$ & Amount of water input \\
Wastewater & $\mathrm{W}_{\mathrm{W}}$ & Amount of water discharged \\
Waste discharge & $\mathrm{W}_{\mathrm{D}}$ & Amount of waste generation \\
\hline
\end{tabular}

Source: Ministry of Environment Government of Japan, 2007

\section{Independent Variable -Corporate Financial Performance}

This study's CFP measurement emphasizes five financial indicators as independent variables (predictors); Equity Ratio (ER); Total Assets (TA), (Becker-Blease, Kaen, Etebari, \& Baumann, 2010; Sritharan, 2015); ROA, (Nakao et al., 2007); ROE (Hart \& Ahuja, 1996; Preston \& O'bannon, 1997; Russo \& Fouts, 1997); and ROS (Hart \& Ahuja,1996; Waddock \& Graves, 1997; Callan \& Thomas, 2009). The particular CFP indicators are summarized on Table 3.

Table 3: Description of Corporate Financial Performance Indicators and Measurements Used in the Analysis

\begin{tabular}{|c|c|c|c|}
\hline Variables & Measurement & Code & Description \\
\hline Equity Ratio & Firm leverage & ER & $\begin{array}{l}\text { Indicates two important financial concepts } \\
\text { - a solvent and sustainable business. }\end{array}$ \\
\hline $\begin{array}{l}\text { Return on } \\
\text { Assets }\end{array}$ & $\begin{array}{l}\text { Firm } \\
\text { profitability }\end{array}$ & ROA & $\begin{array}{l}\text { Measures the return earned on total assets } \\
\text { employed in the business during a period. }\end{array}$ \\
\hline $\begin{array}{l}\text { Return on } \\
\text { Equity }\end{array}$ & $\begin{array}{l}\text { Firm } \\
\text { profitability }\end{array}$ & ROE & $\begin{array}{l}\text { Measures how much profit a company } \\
\text { generates with the money shareholders } \\
\text { have invested during a period. }\end{array}$ \\
\hline $\begin{array}{l}\text { Return on } \\
\text { Sales }\end{array}$ & $\begin{array}{l}\text { Firm } \\
\text { profitability }\end{array}$ & ROS & $\begin{array}{l}\text { Analyzes what percentage of total } \\
\text { company revenues are actually converted } \\
\text { into company profits during a period. }\end{array}$ \\
\hline Total Assets & Firm size & TA & $\begin{array}{l}\text { Total assets used as a firm size indicator - } \\
\text { log of total assets }\end{array}$ \\
\hline
\end{tabular}

Source: Constructed by Authors 


\section{The Model}

In this study, six regression models have been developed based on the variables used to investigate the findings of the studies.

$$
\begin{array}{lll}
R_{M}= & \beta 0+\beta 1 X 1+\beta 2 X 2+\beta 3 X 3+\beta 4 X 4+\beta 5 X 5+\varepsilon & \text { Model I } \\
W_{C}= & \beta 0+\beta 1 X 1+\beta 2 X 2+\beta 3 X 3+\beta 4 X 4+\beta 5 X 5+\varepsilon & \text { Model II } \\
E_{C}= & \beta 0+\beta 1 X 1+\beta 2 X 2+\beta 3 X 3+\beta 4 X 4+\beta 5 X 5+\varepsilon & \text { Model III } \\
G_{H G} G_{(C O 2)}= & \beta 0+\beta 1 X 1+\beta 2 X 2+\beta 3 X 3+\beta 4 X 4+\beta 5 X 5+\varepsilon & \text { Model IV } \\
W_{W}= & \beta 0+\beta 1 X 1+\beta 2 X 2+\beta 3 X 3+\beta 4 X 4+\beta 5 X 5+\varepsilon & \text { Model V } \\
W_{D}= & \beta 0+\beta 1 X 1+\beta 2 X 2+\beta 3 X 3+\beta 4 X 4+\beta 5 X 5+\varepsilon & \text { Model VI }
\end{array}
$$

\section{Where,}

$X 1=\mathrm{ER}$ (Equity Ratio), $X 2=\mathrm{TA}$ (Total Assets), $X 3=\mathrm{ROA}$ (Return on Assets), $X 4=\mathrm{ROE}$ (Return on Equity), $X 5=$ ROA (Return on Sales), $\beta 0=$ constant,$\varepsilon=$ error term.

\section{Results and Discussion}

In this section, the tables and figures use the analyzed data to demonstrate the study findings.

\section{Descriptive Statistics}

Table 4 summarizes descriptive statistics concerning the independent and dependent variables used in the study; and this examination of the descriptive statistics, indicate several issues. The profitability ratios used in CFP variables, ROA, ROE, and ROS, show various average ratios. The ROA used as an independent variable shows a negative 26.1 per cent for the minimum value and a positive 21.2 per cent for the maximum value. This difference ranged from 21 per cent profitability to a 26 per cent loss for the firms. This disparity illustrates another profitable ratio as well. The ROE shows 56 per cent profitability but 437 per cent loss, which is a great example among the selected listed firms for ROE. 
Table 4: Descriptive Statistics of Variables in the Study

\begin{tabular}{|c|c|c|c|c|c|c|}
\hline \multicolumn{7}{|c|}{ CEP - Descriptive Statistics } \\
\hline & $\mathbf{N}$ & Range & Minimum & Maximum & Mean & $\begin{array}{l}\text { Standard } \\
\text { Deviation }\end{array}$ \\
\hline$\overline{\mathrm{E}_{\mathrm{C}}}$ & 478 & 7.035 & 2.190 & 9.225 & 5.660 & 1.418 \\
\hline $\mathrm{GHG}_{(\mathrm{CO} 2)}$ & 582 & 6.000 & 2.000 & 8.000 & 5.270 & 1.075 \\
\hline $\mathrm{R}_{\mathrm{M}}$ & 465 & 7.700 & 0.301 & 8.001 & 5.244 & 1.407 \\
\hline $\mathrm{W}_{\mathrm{D}}$ & 530 & 6.081 & 0.699 & 6.780 & 4.496 & 1.086 \\
\hline $\mathrm{W}_{\mathrm{C}}$ & 556 & 6.980 & 3.102 & 10.082 & 6.408 & 1.198 \\
\hline $\mathrm{W}_{\mathrm{W}}$ & 475 & 6.434 & 2.563 & 8.997 & 6.297 & 1.315 \\
\hline $\begin{array}{l}\text { Valid N } \\
\text { (listwise) }\end{array}$ & 300 & & & & & \\
\hline \multicolumn{7}{|c|}{ CFP - Descriptive Statistics } \\
\hline$\overline{\mathrm{ER}}$ & 594 & 4.464 & 0.000 & 4.464 & 0.462 & 0.428 \\
\hline TA & 594 & 2.631 & 4.676 & 7.307 & 5.895 & 0.550 \\
\hline ROA & 590 & 0.473 & -0.261 & 0.212 & 0.020 & 0.042 \\
\hline $\mathrm{ROE}$ & 590 & 4.942 & -4.374 & 0.568 & 0.033 & 0.215 \\
\hline ROS & 593 & 0.457 & -0.144 & 0.313 & 0.052 & 0.049 \\
\hline $\begin{array}{l}\text { Valid N } \\
\text { (listwise) }\end{array}$ & 590 & & & & & \\
\hline
\end{tabular}

Source: Survey Data

Note: $\mathrm{GHG}_{(\mathrm{CO} 2)}=$ Greenhouse gas, $\mathrm{R}_{\mathrm{M}}=$ Raw materials, $\mathrm{E}_{\mathrm{C}}=$ Electricity consumed, $\mathrm{W}_{\mathrm{C}}=$ Water consumed, $\mathrm{W}_{\mathrm{W}}=$ Waste water, $\mathrm{W}_{\mathrm{D}}=$ Waste discharge, $\mathrm{ER}=$ Equity Ratio, $\mathrm{TA}=$ Total Assets, ROA=Return on Assets, $\mathrm{ROE}=$ Return on Equity, ROA=Return on Sales.

The ROS shows 31 per cent profitability and 14.4 per cent loss. The average value of firm size (total assets) is 589 per cent, with a range of 467 per cent to 730 per cent, whereas the average firm leverage rate (equity ratio) is 46 per cent. Furthermore, the results show that the most volatile (unstable) variables are CEP variables. Electrical consumption $\left(E_{C}\right)$ is the most volatile variable in the study, with a Standard Deviation (SD) of 1.418. The least volatile (most stable) variable is $\mathrm{GHG}_{(\mathrm{CO} 2)}$, with an SD of 1.075. From the perspective of CFP, the least volatile variable is ROA, with an SD of 0.042 , and the most volatile variable is the log of total assets.

\section{Correlation Matrix}

Table 5 shows the correlation matrix of dependent and independent variables for the purpose of examining the existing correlation among these variables. 
Table 5: Correlation Matrix

\begin{tabular}{|c|c|c|c|c|c|c|}
\hline \multirow{2}{*}{$\begin{array}{c}\text { Dependent } \\
\text { Variables }\end{array}$} & & \multicolumn{4}{|c|}{ Independent Variables } & \multirow[b]{2}{*}{ ROA } \\
\hline & & TA & ER & ROS & ROE & \\
\hline \multirow{3}{*}{$\mathbf{G H G}_{(\mathrm{CO} 2)}$} & Pearson correlation & $0.440^{* *}$ & $-0.188^{\text {** }}$ & $-0.205^{* * *}$ & -0.063 & $-0.140^{* * *}$ \\
\hline & p-value & 0.000 & 0.000 & 0.000 & 0.065 & 0.000 \\
\hline & $\mathrm{N}$ & 582 & 582 & 581 & 578 & 578 \\
\hline \multirow{3}{*}{$\mathbf{R}_{\mathbf{M}}$} & Pearson correlation & $0.468^{* * *}$ & $-0.306^{* *}$ & $-0.214^{* *}$ & -0.033 & $-0.121^{* *}$ \\
\hline & p-value & 0.000 & 0.000 & 0.000 & 0.239 & 0.005 \\
\hline & $\mathrm{N}$ & 465 & 465 & 465 & 464 & 464 \\
\hline \multirow{3}{*}{$\mathbf{W}_{\mathbf{C}}$} & Pearson correlation & $0.397^{* *}$ & $-0.188^{* *}$ & $-0.144^{* *}$ & -0.038 & $-0.093^{*}$ \\
\hline & $\mathrm{p}$-value & 0.000 & 0.000 & 0.000 & 0.188 & 0.014 \\
\hline & $\mathrm{N}$ & 556 & 556 & 555 & 554 & 554 \\
\hline \multirow{3}{*}{$\mathbf{E}_{\mathbf{C}}$} & Pearson correlation & $0.160^{* * *}$ & $-0.087^{*}$ & $-0.083^{*}$ & -0.051 & -0.050 \\
\hline & p-value & 0.000 & 0.028 & 0.034 & 0.135 & 0.139 \\
\hline & $\mathrm{N}$ & 478 & 478 & 478 & 477 & 477 \\
\hline \multirow{3}{*}{$\mathbf{W}_{\mathbf{W}}$} & Pearson correlation & $0.352^{* * *}$ & $-0.143^{* *}$ & $-0.080^{*}$ & -0.020 & -0.035 \\
\hline & p-value & 0.000 & 0.001 & 0.041 & 0.334 & 0.222 \\
\hline & $\mathrm{N}$ & 475 & 475 & 474 & 473 & 473 \\
\hline \multirow{3}{*}{$\mathbf{W}_{\mathbf{D}}$} & Pearson correlation & $0.485^{* *}$ & $-0.215^{* *}$ & $-0.141^{* *}$ & $0.110^{* *}$ & -0.009 \\
\hline & $p$-value & 0.000 & 0.000 & 0.001 & 0.005 & 0.416 \\
\hline & $\mathrm{N}$ & 530 & 530 & 529 & 529 & 529 \\
\hline
\end{tabular}

Source: Survey Data

Note: $* *=$ Correlation is significant at the 0.01 level (1-tailed), $*=$ Correlation is significant at the 0.05 level (1-tailed), $\mathrm{GHG}_{(\mathrm{CO} 2)}=$ Greenhouse gas, $\mathrm{R}_{\mathrm{M}}=$ Raw materials, $\mathrm{E}_{\mathrm{C}}=$ Electricity consumed, $\mathrm{W}_{\mathrm{C}}=$ Water consumed, $\mathrm{W}_{\mathrm{W}}=$ Wastewater, $\mathrm{W}_{\mathrm{D}}=$ Waste discharge, $\mathrm{ER}=$ Equity Ratio, TA=Total Assets, ROA=Return on Assets, ROE=Return on Equity, ROA=Return on Sales.

The results reveal that $\mathrm{GHG}_{(\mathrm{CO})}, \mathrm{R}_{\mathrm{M}}, \mathrm{W}_{\mathrm{C}}, \mathrm{E}_{\mathrm{C}}, \mathrm{W}_{\mathrm{W}}$, and $\mathrm{W}_{\mathrm{D}}$ show both a positive and negative correlation among the predictors. The greenhouse gas emission variable positively correlated with the firm size (TA) as 44 per cent $(\mathrm{p}=0.000)$, whereas it was negatively correlated with the firms' financial leverage (ER) (18.8 per cent, $\mathrm{p}=0.000$ ), ROS (20.5 per cent, $\mathrm{p}=0.000$ ), and ROA (14 per cent, $\mathrm{p}=0.00$ ). There is negative but not significant correlation between $\mathrm{ROE}$ and $\mathrm{GHG}_{(\mathrm{CO} 2)}$. The total amount of raw material $\left(\mathrm{R}_{\mathrm{M}}\right)$ input and water input $\left(\mathrm{W}_{\mathrm{C}}\right)$ amount of the firms show the same correlation results as greenhouse gas variables. Firm size shows positive correlation $(\mathrm{p}=0.000)$ among $\mathrm{R}_{\mathrm{M}}$ and $\mathrm{W}_{\mathrm{C}}$, but $\mathrm{ER}$, ROS, and ROA have negative correlation $(\mathrm{p}=0.000) . \mathrm{R}_{\mathrm{M}}$ and $\mathrm{W}_{\mathrm{C}}$ have a statistically insignificant - negative correlation for the ROE of the firms.

The amount of energy input $\left(\mathrm{E}_{\mathrm{C}}\right)$ positively correlated with the firm size and negatively correlated with the firms' leverage $(\mathrm{r}=-0.087)$ and the ROS $(\mathrm{r}=-0.083)$, whereas ROE and ROA showed negative but insignificant 
relationships. The amount of firms' wastewater $\left(\mathrm{W}_{\mathrm{W}}\right)$ and firm size showed positive and statistically significant relationships. However, $\mathrm{W}_{\mathrm{W}}$ showed a significant negative correlation for firm financial leverage and ROS $(r=0.080 ; p=0.041)$. Finally, the amount of waste generation $\left(\mathrm{W}_{\mathrm{D}}\right)$ showed a positive and significant correlation between firm size and ROE. A negative correlation was indicated among ER and ROS for $\mathrm{W}_{\mathrm{D}}$. The ROA also had a negative correlation with $\mathrm{W}_{\mathrm{D}}$ which however was statistically insignificant $(\mathrm{p}=0.416)$. The correlation table implies that some dependent variables indicate positive and significant correlation among predictors, while other dependent variables show either negative but significant or negative but insignificant correlations among the financial variables. This implies mixed hypothesis testing results due to either strong or weak evidence against the null hypothesis.

\section{Regression Analysis}

Tables 6 and Table 7 show the Regression Analysis out comes using dependent and independent variables. Table 6 features summaries of Models I to VI, which illustrate the overall fit of the model.

Table 6: Results of Regression Analysis

\begin{tabular}{|c|c|c|c|c|c|c|c|c|c|}
\hline \multirow[b]{2}{*}{ Model } & \multirow[b]{2}{*}{$\mathbf{R}$} & \multirow[b]{2}{*}{$\mathbf{R}^{2}$} & \multirow[b]{2}{*}{$\begin{array}{l}\text { Adjusted } \\
\mathbf{R}^{2}\end{array}$} & \multirow{2}{*}{$\begin{array}{l}\text { Std. Error } \\
\text { of the } \\
\text { Estimate }\end{array}$} & \multicolumn{5}{|c|}{ Change Statistics } \\
\hline & & & & & $\begin{array}{c}\text { R Square } \\
\text { Change }\end{array}$ & $\begin{array}{c}\text { F } \\
\text { Change }\end{array}$ & df1 & df 2 & $\begin{array}{c}\text { Sig. F } \\
\text { Change }\end{array}$ \\
\hline I & $0.473^{\mathrm{a}}$ & 0.224 & 0.217 & 0.951 & 0.224 & 33.014 & 5 & 572 & 0.000 \\
\hline II & $0.498^{\mathrm{a}}$ & 0.248 & 0.239 & 1.220 & 0.248 & 30.133 & 5 & 458 & 0.000 \\
\hline III & $0.411^{\mathrm{a}}$ & 0.169 & 0.161 & 1.093 & 0.169 & 22.276 & 5 & 548 & 0.000 \\
\hline IV & $0.179^{\mathrm{a}}$ & 0.032 & 0.022 & 1.404 & 0.032 & 3.125 & 5 & 471 & 0.009 \\
\hline V & $0.525^{\mathrm{a}}$ & 0.275 & 0.268 & 0.929 & 0.275 & 39.715 & 5 & 523 & 0.000 \\
\hline VI & $0.356^{\mathrm{a}}$ & 0.127 & 0.118 & 1.232 & 0.127 & 13.590 & 5 & 467 & 0.000 \\
\hline
\end{tabular}

Source: Survey Data

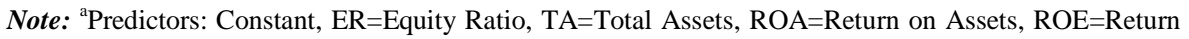
on Equity, ROA=Return on Sales.

As illustrated in Table $6, \mathrm{R}^{2}$ values suggest that 22.4 per cent, 24.8 per cent, 16.9 per cent, 3.2 per cent, 27.5 per cent, and 12.7 per cent of the variability observed in Models I to VI were verified by the variations in the predictors used in the study. Models I to VI show less than 30 per cent variations in the predictors; therefore, the remaining 77.6 per cent, 75.2 per cent, 83.1 per cent, 96.8 per cent, 72.5 per cent, and 87.3 per cent of the variations in the models were related to other variables that were not 
illustrated in the models. These unknown variables can impact the Environmental Performance of firms; hence, this demonstrates a scope for future research that must be considered.

Table 7 is concerned with the parameters of the models I to VI. The predictors in the models indicated both positive and negative $\beta$-values. Model I has negative $\beta$-values for ROS (-3.980) and ROE (-0.016). Model II has two negative $\beta$-values (ER and ROS), and Model III has three negative $\beta$-values (ER, ROS, and ROE). Models IV and VI have the same outcomes as Model III, and Model V has two negative $\beta$-values, as does Model II. Table 7 shows another concerning outcome, which can be elaborated as to what extent $\beta$-values would vary across samples. This implies that the predictor makes a significant contribution to the model if the $p$-value is less than 5 per cent. Hair (2007) proposed using the $t$-value to determine which independent variables have statistically significant independent coefficients. Additionally, Field (2013) proposed that IBM SPSS provides the exact probability that the observed value of $t$ would occur if the value of $\beta$ was 0 . Therefore, if the $p$-value is 5 per cent, the scientist can assume that $\beta$ is significantly different from zero, and that the predictor or independent variable makes a significant contribution to the outcome (Field, 2013). According to Models I to VI, $p$-values for firm size $(\beta=0.857)$ indicate positive significant contributions toward greenhouse gas emissions of firms, and ROS indicates a negative contribution $(\beta=-3.980)$ at a significant level. Models II and V show that firm size $(\beta=1.024)$, ER $(\beta=-0.328)$, and ROS $(\beta=-4.684)$ significantly contribute in each model. Model III also has the same output as does Model I. Models IV and VI show the same $p$-values because only firm size indicates a positive contribution.

Firm size exhibits a positive association with dependent variables in all six models in a significant manner. The ROS exhibits a negative association with dependent variables in Models I, II, III, and V. Furthermore, Firm Leverage (ER) shows a negative association with dependent variables in Model II, and other models show no association with ER. ROE shows a positive association with dependent variables only in Model V. As exhibited in Table 7, $t$-values are significant for independent variables in the models. 
Table 7: Coefficients

\begin{tabular}{|c|c|c|c|c|c|c|c|}
\hline \multirow[t]{2}{*}{ Model } & \multicolumn{2}{|c|}{ Unstandardized } & \multicolumn{3}{|c|}{ Standardized } & \multicolumn{2}{|c|}{$\begin{array}{l}\text { 95.0\% Confidence } \\
\text { Interval for B }\end{array}$} \\
\hline & B & Std. Error & B & t-value & p-value & Lower Bound & Upper Bound \\
\hline \multicolumn{8}{|c|}{ MI-GHG $_{(\mathrm{CO} 2)}$} \\
\hline (constant) & 0.381 & 0.480 & & 0.795 & 0.427 & -0.561 & 1.323 \\
\hline TA & 0.857 & 0.078 & 0.440 & 11.033 & 0.000 & 0.705 & 1.010 \\
\hline ER & 0.072 & 0.103 & 0.029 & 0.699 & 0.485 & -0.131 & 0.275 \\
\hline ROS & -3.980 & 1.201 & -0.181 & -3.314 & 0.001 & -6.339 & -1.621 \\
\hline ROE & -0.016 & 0.248 & -0.003 & -0.065 & 0.948 & -0.502 & 0.470 \\
\hline ROA & 0.710 & 1.671 & 0.028 & 0.425 & 0.671 & -2.573 & 3.993 \\
\hline \multicolumn{8}{|l|}{ MII-R ${ }_{M}$} \\
\hline (constant) & -0.481 & 0.702 & & -0.684 & 0.494 & -1.861 & 0.900 \\
\hline TA & 1.024 & 0.113 & 0.404 & 9.076 & 0.000 & 0.802 & 1.246 \\
\hline ER & -0.328 & 0.138 & -0.110 & -2.384 & 0.018 & -0.599 & -0.058 \\
\hline ROS & -4.684 & 1.878 & -0.148 & -2.494 & 0.013 & -8.375 & -0.993 \\
\hline ROE & 0.087 & 0.330 & 0.014 & 0.264 & 0.792 & -0.561 & 0.736 \\
\hline $\mathrm{ROA}$ & 1.922 & 2.373 & 0.058 & 0.810 & 0.418 & -2.741 & 6.585 \\
\hline \multicolumn{8}{|l|}{ MIII-W $_{C}$} \\
\hline (constant) & 1.783 & 0.558 & & 3.198 & 0.001 & 0.688 & 2.878 \\
\hline TA & 0.814 & 0.090 & 0.378 & 8.998 & 0.000 & 0.636 & 0.991 \\
\hline ER & -0.050 & 0.119 & -0.019 & -0.422 & 0.673 & -0.285 & 0.184 \\
\hline ROS & -3.059 & 1.396 & -0.127 & -2.191 & 0.029 & -5.801 & 0.317 \\
\hline ROE & -0.004 & 0.285 & -0.001 & -0.015 & 0.988 & -0.565 & 0.556 \\
\hline ROA & 0.920 & 1.938 & 0.033 & 0.475 & 0.635 & -2.886 & 4.726 \\
\hline \multicolumn{8}{|l|}{ MIV-E ${ }_{C}$} \\
\hline (constant) & 3.658 & 0.738 & & 4.955 & 0.000 & 2.207 & 5.109 \\
\hline TA & 0.360 & 0.119 & 0.147 & 3.011 & 0.003 & 0.125 & 0.594 \\
\hline ER & -0.048 & 0.154 & -0.016 & -0.313 & 0.755 & -0.351 & 0.255 \\
\hline ROS & -2.564 & 1.866 & -0.092 & -1.374 & 0.170 & -6.231 & 1.103 \\
\hline ROE & -0.357 & 0.368 & -0.060 & -0.968 & 0.333 & -1.081 & 0.367 \\
\hline ROA & 2.256 & 2.568 & 0.072 & 0.878 & 0.380 & -2.790 & 7.301 \\
\hline \multicolumn{8}{|l|}{$M V-W_{D}$} \\
\hline (constant) & -0.884 & 0.484 & & -1.826 & 0.068 & -1.836 & 0.067 \\
\hline TA & 0.941 & 0.079 & 0.480 & 11.947 & 0.000 & 0.786 & 1.095 \\
\hline ER & -0.002 & 0.102 & -0.001 & -0.022 & 0.982 & -0.202 & 0.197 \\
\hline ROS & -4.095 & 1.191 & -0.187 & -3.439 & 0.001 & -6.435 & -1.756 \\
\hline ROE & 0.710 & 0.243 & 0.148 & 2.919 & 0.004 & 0.232 & 1.188 \\
\hline ROA & 1.748 & 1.662 & 0.070 & 1.051 & 0.294 & -1.518 & 5.014 \\
\hline \multicolumn{8}{|l|}{ MVI-W $_{W}$} \\
\hline (constant) & 1.475 & 0.695 & & 2.123 & 0.034 & 0.110 & 2.840 \\
\hline TA & 0.840 & 0.113 & 0.343 & 7.399 & 0.000 & 0.617 & 1.063 \\
\hline ER & -0.020 & 0.137 & -0.007 & -0.149 & 0.882 & -0.289 & 0.249 \\
\hline ROS & -2.551 & 1.758 & -0.096 & -1.451 & 0.148 & -6.006 & 0.905 \\
\hline ROE & -0.017 & 0.330 & -0.003 & -0.052 & 0.958 & -0.666 & 0.631 \\
\hline ROA & 1.890 & 2.316 & 0.064 & 0.816 & 0.415 & -2.661 & 6.440 \\
\hline
\end{tabular}

Source: Survey Data

Note: M I: Dependent variable $=\mathrm{GHG}_{\mathrm{CO} 2}$, M II: Dependent variable $=\mathrm{RM}, \mathrm{M}$ III: Dependent variable $=W C$, M IV: Dependent variable $=E C, M$ V: Dependent variable $=W D, M$ VI: Dependent variable $=\mathrm{WW}$. 
This reveals that the firm size indicator as measured by the log of total assets contributes to the determination of greenhouse gas, raw material input, water consumption, electricity consumption, waste generation, and waste water output of the firms listed in Japan from 2008 to 2014. However, financial leverage, ROS, and ROE make various contributions to determining the dependent variables in the models. Additionally, ROA, one of the profitable ratios, makes no contribution towards the determination due to its insignificant $t$-values.

This study examined the effects of CEP on CFP of the firms listed on the TSK for a period of seven-years (2008 to 2014). The quantitative approach was taken into the consideration; and hence, correlation and multiple regression methods have been used in this study. The outcomes have been elaborated from the research findings to determine the hypotheses (Table 8).

Table 8: Hypothesis Testing Outcomes

\begin{tabular}{|c|c|}
\hline Hypothesis & Result \\
\hline H1: There is an impact of environmental performance on firms' size. & Accepted \\
\hline $\begin{array}{l}\text { H2: There is an impact of environmental performance on financial } \\
\text { leverage. }\end{array}$ & Rejected \\
\hline H3:There is an impact of environmental performance on profitability. & Rejected \\
\hline
\end{tabular}
Source: Constructed by Authors

Similar to Cormier and Magnan (2007) and unlike Nagayama and Takeda (2007) and Nakao et al. (2007), the outcomes of the correlation matrix (Table 5) showed the existence of a mixed relationship between environmental performance indicators and financial performance indicators with the exception of the firm size. Firm size showed a positive correlation among dependent variables at a significant level; however, $r$-values are less than 50 per cent for each environmental indicator. Also, in line with the results of Table 7 for Models I to VI, among the predictors, of all dependent variables, firm size shows that $\beta$-values are significant; therefore, $\mathrm{H}_{1}$ cannot be rejected. According to the findings, other predictors do not contribute as much as does firm size. According to the findings, ROS has negative $\beta$ values, indicating negative relationships for Models I, II, III, and V; however, Models IV and VI do not show any significant contribution to the profitability ratio. ROE indicates a positive relationship $(\beta=0.710)$ for 
Model V only, and no contribution for other models. The financial leverage measurement shows a negative relationship $(\beta=-0.3280)$ for Model II, but other models show no contribution either; therefore, $\mathrm{H}_{2}$ and $\mathrm{H}_{3}$ can be rejected. Overall, observations from Table 6 , the results for $R^{2}$ values, showed that there might be other significant variables for the variations in the models that are not shown. The remaining 77.6 per cent, 75.2 per cent, 83.1 per cent, 96.8 per cent, 72.5 per cent, and 87.3 per cent of the variations in the models were related to other variables, hence, the remaining variations indicate that differences made by adding new predictors to the models might be better predictors for the environmental performance relationship.

Aras and Crowther (2007) argued that the focus of CSR is confusing the real situation regarding the effect of corporate activity upon the external environment. Unlike financial performance, there is no clear measurement standard from the CSR context due to the subject matter. Furthermore, CSR is a not a quantifiable theme of finance management, as finance-based analysis operates under market rules supporting mandatory regulations, but these conditions do not apply to CSR. Additionally, particular authors have specified that the analysis of sustainability only recognizes a Twodimensional Approach (i.e. environmental and social). This current study uses only the CEP and CFP, which represent two dimensions as well. Aras and Crowther (2009) argued for a Four-Dimensional Model which includes the aspects of corporate sustainability; social influence, environmental impact, organizational culture, and finance. They also revealed a model that is broader and more complete than those of others. Therefore, they recommend recognizing these four dimensions as keys to sustainability.

From a Japanese perspective, scholars have also obtained consistently mixed results. Iwata and Okada (2011) claimed that, while reducing greenhouse gas increased ROE for manufacturing firms in Japan, ROS does not show significant results on the long run. Contrary to the findings of Iwata and Okada (2010), Hart \& Ahuja (1996) claimed that their study of pollution prevention and emissions reduction initiatives showed that operating performance indicators, ROA and ROS, are significantly enhanced one year after the reduction of emissions. The lacking gains from ROE may reflect the time required to increase operating efficiencies. 
Supporting the positive linkage of CEP and CFP, Nishitani and Kokubu (2012) aimed to contribute to theory development on the linkage of voluntary and mandatory environmental performance and competiveness of the firm. This study revealed a positive correlation between GHG emissions and financial performance.

\section{Conclusion}

Our main objective has been to identify a link between CEP and CFP from the perspective of sustainability and Japanese corporate responsibility. The study allocated eleven indicators, both independent and dependent variables. There are five independent variables (CFP), including financial leverage, profitability, and firm size. Under the profitability ratio, there are three indicators; leverage and size have one indicator each. The dependent variables for CEP have six indicators; greenhouse gas, water input, raw material input, wastewater, electricity consumption, and waste discharge. The correlation matrix and regression models were included in the analysis. Eighty five companies from various industries were chosen from companies listed on the TSK 2008 to 2014, based on data availability from sustainable disclosure information. Three hypotheses $\left(\mathrm{H}_{1}, \mathrm{H}_{2}\right.$, and $\left.\mathrm{H}_{3}\right)$ were developed for further evaluation of the effect of financial indicators on environmental performance.

This study indicates mixed results for hypothesis testing, accepting a single hypothesis and rejecting two other hypotheses. The accepted $\mathrm{H}_{1}$ shows that environmental performance significantly impacts firm size. However, the rejected $\mathrm{H}_{2}$ and $\mathrm{H}_{3}$ indicate that environmental performance has no significant impact on financial leverage and profitability due to a weak relationship or insignificant outcomes. Financial leverage on the other hand does not show a strong impact correlation with environmental performance related aspects. Furthermore, the selected profitability ratios, including ROA, ROE, and ROS, were mixed. Only ROS showed few significant but weak relationships between environmental performance indicators as compared to ROA and ROE; nevertheless, ROA showed neither a significant positive or negative contribution. According to the coefficient of determination ( $R^{2}$ values), the analysis found that there might be other variables that predict the relationship between environmental performance and financial performance that were not considered in this 
study. Therefore, the study may prove that there are some other factors contributing to the positive linkage of these two aspects. There is an inherent difficulty in trying to measure CSR performance quantitatively because volunteering companies had varying objectives for their CSR activities. Hart and Ahuja (1996) also found mixed results in some cases; ROA had a positive relationship with CEP for two variables but a negative in relationship in other cases.

Unlike financial measurements and auditing, there is no clear measurement standard for CSR context. CSR is a not a quantifiable subject, such as finance management, because finance-based analysis operates under market rules supporting mandatory regulations, however, these conditions apply to CSR matters. This notion remains consistent with the study of Aras and Crowther (2009). They argued that the focus of CSR is confusing the real situation regarding the effect of corporate activity upon the external environment. The authors also specified that analyses of sustainability only recognize two dimensions (i.e: environmental and social). This study also discovered only two dimensions, that is environmental and finance, according to the Aras and Crowther model (2007). These two authors (Aras \& Crowther, 2008) argued for a Four-dimensional Model of Corporate Sustainability; social influence, environmental impact, organizational culture, and finance. They also revealed a model that is broader and more complete than those of others. Therefore, they recommend recognizing these four dimensions as keys to sustainability.

The mixed results that are brought to light from even the Japanese perspective question as to whom should be responsible when there is a disparity in the firms' environmental performance and financial performance linkage; this is an additional consequence that is related to the corporate sustainability performance criteria. Tanimoto (2013) showed that establishing a CSR department would not lead towards an automatic embracing of CSR within an organization. Tanimoto (2013) also further explored if CSR was a set of policies and practices integrated into the entire management process, how the CSR function has been developed, and its purpose in Japanese companies, because a socially responsible management requires the total consideration in all aspects of business operation: manufacturing, marketing, environment, risk, customer management etc. 
According to one study (Tanimoto, 2013), some executives in management do not know what role CSR should have. From the beginning, some companies found that a CSR department is a niche field within the organization because other departments already had established authority to process their own roles in the organization and so, for the reasons mentioned above, CSR departments will experience certain levels of conflict or confusion. The question of how far the role of CSR can be focused on, in the organization while giving attention to both internal (shareholder/ management) and external (stakeholders) domains remain unanswered. Recent literature argues CSR to be important for successful business strategy, and that corporate governance is intricately connected with CSR. The management must be committed to incorporating CSR into the company's total process as simply establishing a relevant division is insufficient when ensuring automatic CSR functioning (Tanimoto, 2013).

The few limitations of this study as are follows: firstly, this was a study carried out with information gathered from secondary data, which involves some restrictions in data collection, e.g., some important CSR data was improper or not conveyed in reports. Therefore, the findings could encourage improvement in corporate sustainability reporting for Japanese corporations. This is also an important aspect of accountability; since exposing environmental obligations to a wider spectrum of stakeholders is one criterion of the sustainability management ethos. Furthermore, this study did not concentrate on just the manufacturing sector, as most studies did in the past; rather, it focused on almost every industrial sector in Japan. Some could argue that this approach may not provide adequate information due to the results obtained; arguably, CSR and sustainability management contribute to almost every sector in an industrial format by enhancing sustainability development.

This study attempted to reveal a relationship between the environmental performance and financial performance of a company to demonstrate the occurrence of sustainability management and corporate responsibility. This idea is still being debated in a global context, as seen in previous studies. Some scholars, such as Cohen, Fenn and Konar (1995) concluded that their research on environmental and financial performance would require considerable times-series data. Studies on the relationship of these two 
domains in CSR have inconclusive results; some predictions were positive, while some were either negative or had no relationship. This may be due to the limited knowledge accumulated upon which to build a theory that is universally accepted.

There is much to discover across a broader spectrum about the relationship between CEP and CFP. CSR is a mode to elaborate responsible business protocols; however, the ethos may not have been discovered as yet. Therefore, the inconsistent results of the relationship between financial performance vs. environmental performance in the corporate domain may not be solved by the academia; however, the management's accountability towards CSR could be another reason for the inconsistent results. Recent literature argues that CSR is important for successful business strategy and corporate governance. To incorporate CSR into a companies' total process must include a commitment on the part of management since simply establishing a relevant division is insufficient to ensure automatic CSR functioning.

\section{References}

Aggarwal, P. (2013). Impact of corporate governance on corporate financial performance. IOSR Journal of Business and Management, 13(3), 1-5.

Aggarwal, P. (2013). Sustainability reporting and its impact on corporate financial performance: A literature review. Indian Journal of Commerce and Management Studies, 4(3), 51-59.

Aras, G., \& Crowther, D. (2007). What level of trust is needed for sustainability? Social Responsibility Journal, 3(3), 60-68.

Aras, G., \& Crowther, D. (2008). Governance and sustainability: An investigation into the relationship between corporate governance and corporate sustainability. Management Decision, 46(3), 433-448.

Aras, G., \& Crowther, D. (2009). Corporate sustainability reporting: A study in disingenuity? Journal of Business Ethics, 87(1), 279.

Aupperle, K. E., Carroll, A. B., \& Hatfield, J. D. (1985). An empirical examination of the relationship between corporate social responsibility and profitability. Academy of Management Journal, 28(2), 446-463.

Becker-Blease, J. R., Kaen, F. R., Etebari, A., \& Baumann, H. (2010). Employees, firm size and profitability in US manufacturing industries. Investment Management and Financial Innovations, 7(2), 7-23. 
Bowen, H. R. (1953). Social responsibilities of the businessman. New York, NY: Harper.

Brouwers, R., Schoubben, F., Van Hulle, C., \& Van Uytbergen, S. (2014). The link between corporate environmental performance and corporate value: A literature review. Review of Business and Economic Literature, 58(4), 343-374.

Callan, S. J., \& Thomas, J. M. (2009). Corporate financial performance and corporate social performance: An update and reinvestigation. Corporate Social Responsibility and Environmental Management, 16(2), 61-78.

Carroll, A. B. (1979). A three-dimensional conceptual model of corporate performance. Academy of Management Review, 4(4), 497-505.

Cannon, T. (1992). Corporate Responsibility. London: Pitman Publishing.

Cheit, E. F. (1964). Why managers cultivate social responsibility. California Management Review, 7(1), 3-22.

Christmann, P. (2000). Effects of best practices of environmental management on cost advantage: The role of complementary assets. Academy of Management Journal, 43(4), 663-680.

Cohen, M.A., Fenn, S. A., \& Konar, S. (1995). Environmental and Financial Performance: Are They Related? Washington DC: Investor Responsibility Research Center.

Cormier, D., \& Magnan, M. (2007). The revisited contribution of environmental reporting to investors' valuation of a firm's earnings: An international perspective. Ecological Economics, 62(3), 613-626.

Crane, A., Matten, D., McWilliams, A., Moon, J., \& Siegel, D. (2008). Introduction: The corporate social responsibility agenda. In Crane, A., Matten, D., McWilliams, A., Moon, J., \& Siegel, D. (Eds), The oxford handbook of corporate social responsibility (pp.3-18). Oxford: Oxford University Press.

Davis, K. (1960). Can business afford to ignore social responsibilities? California Management Review, 2(3), 70-76.

Davis, K., \& Blomstrom, R. L. (1966). Business and its environment. . New York, NY: McGraw-Hill.

Dowell, G., Hart, S. and Yeung, B., 2000. Do corporate global environmental standards create or destroy market value? Management Science, 46(8), 1059-1074.

Drucker, P.F. (1946). The concept of the corporation. New York, NY: John Day Company. 
Feldman, S.J., Soyka, P.A., \& Ameer, P. G. (1997). Does improving a firm's environmental management system and environmental performance result in a higher stock price? The Journal of Investing, 6(4), 87-97.

Field, A. (2013). Discovering statistics using SPSS (3rd ed.). New Delhi: SAGE Publications India Pvt Ltd.

Fontaine, M. (2013). Corporate social responsibility and sustainability: the new bottom line? International Journal of Business and Social Science, 4(4), 110-119.

Friedman, M. (1970, September). The social responsibility of business is to increase its profits. New York Times Magazine. Retrieved from https://www.colorado.edu/studentgroups/libertarians/issues/friedmansoc-resp-business.html

Fujii, H., Kimbara, T., Kaneko, S., \& Gibson, D. (2009). Mechanism of corporate environmental management: Empirical study for Japanese and US companies. Paper presented at the Twelfth International Conference on Technology Policy and Innovation, Porto, Portugal. Retrieved from http://www.ic2.utexas.edu/ictpi/mirror/porto2009/papers/06_Mechanis m\%20of\%20Corporate\%20Environmental\%20Management_Empirical. pdf

Garriga, E., \& Mele, D. (2004). Corporate social responsibility theories: Mapping the territory. Journal of Business Ethics, 53(1-2), 51-71.

Greenwood, W. T. (1964). Issues in business and society: Readings and cases. Massachusetts: Houghton Mifflin.

Hair, J. F. (2007). Research methods for business. Hoboken, NJ: John Wiley $\&$ Sons Ltd.

Hart, S. L., \& Ahuja, G. (1996). Does it pay to be green? An empirical examination of the relationship between emission reduction and firm performance. Business Strategy and the Environment, 5(1), 30-37.

Hassel, L., Nilsson, H., \& Nyquist, S. (2005). The value relevance of environmental performance. European Accounting Review, 14(1), 4161.

Hoffma, A. (2004). Winning the greenhouse game. Harvard Business Review, 82(4), 20-21. 
Global Reporting Initiatives (2013). Report or Explain: A Smart EU Policy Approach to Non-Financial Information Disclosure. Retrieved from https://www.globalreporting.org/resourcelibrary/GRI-non-paper-Reportor-Explain.pdf

Ivancevich, P., Lorenzi, S. Skinner, \& P. Crosby (1997). Management quality and competitiveness ( $2 \mathrm{nd}$ ed.). Chicago: Irwin.

Iwata, H., \& Okada, K. (2011). How does environmental performance affect financial performance? Evidence from Japanese manufacturing firms. Ecological Economics, 70(9), 1691-1700.

Jacobs, B.W., Singhal, V.R., \& Subramanian, R. (2010). An empirical investigation of environmental performance and the market value of the firm. Journal of Operations Management, 28(5), 430-441.

Jaffe, A. B., Peterson, S. R., Portney, P. R., \& Stavins, R. N. (1995). Environmental regulation and the competitiveness of US manufacturing: what does the evidence tell us? Journal of Economic literature, 33(1), 132-163.

Jennifer Ho, L. C., \& Taylor, M. E. (2007). An empirical analysis of triple bottom-line reporting and its determinants: Evidence from the United States and Japan. Journal of International Financial Management \& Accounting, 18(2), 123-150.

Judge, W.Q., \& Douglas, T. J. (1998). Performance implications of incorporating natural environmental issues into the strategic planning process: An empirical assessment. Journal of Management Studies, 35(2), 241-262.

Kawamura, M. (2004). The evolution of corporate social responsibility in Japan - Part 1: Parallels with the history of corporate reform. Tokyo: NLI Research Institute.

Klonoski, R. J. (1991). Foundational considerations in the corporate social responsibility debate. Business Horizons, 34(4), 9-18.

Konar, S., \& Cohen, M. A. (2001). Does the market value environmental performance? The review of economics and statistics, 83(2), 281-289.

KPMG (2011). KPMG International survey of corporate responsibility reporting 2011. Amsterdam, the Netherlands: Author.

KPMG (2015). KPMG International survey of corporate responsibility reporting 2015. Amsterdam, The Netherlands: Author.

Mason, E. S. (1960). The corporation in modern society. Cambridge: Harvard University Press. 
McGuire, J. W. (1963). Business and society. New York, NY: McGraw-hill. Mele, D. (2008). Corporate social responsibility theories. In Crane, A., Matten, D., McWilliams, A., Moon, J., \& Siegel, D. (Eds), The oxford handbook of corporate social responsibility (pp.47-82). Oxford: Oxford University Press.

Miles, M.P., \& Covin, J. G. (2000). Environmental marketing: A source of reputational, competitive, and financial advantage. Journal of business Ethics, 23(3), 299-311.

Murphy, C.J. (2002). The profitable correlation between environmental and financial performance: A review of the research. Retrieved from http://www.lightgreen.com/pc.pdf

Ministry of Environment Government of Japan (2007). Environmental reporting guidelines: Towards a sustainable society. Retrieved fromhttps://www.env.go.jp/en/policy/economy/erg2007.pdf

Nagayama, S., \& Takeda, F. (2007). An empirical study on the impact of environmentally friendly news on stock prices in Japan. Global Business and Economics Anthology, 1, 129-137.

Nakao, Y., Amano, A., Matsumura, K., Genba, K., \& Nakano, M. (2007). Relationship between environmental performance and financial performance: An empirical analysis of Japanese corporations. Business Strategy and the Environment, 16(2), 106-118.

Nishitani, K., \& Kokubu, K. (2012). Why does the reduction of greenhouse gas emissions enhance firm value? The case of Japanese manufacturing firms. Business Strategy and the Environment, 21(8), 517-529.

Nishitani, K., \& Kokubu, K. (2014). The role of corporate environmental disclosures: An empirical analysis of the influence of a firms environmental initiatives on its economic performance (Discussion Paper No. 2014-34). Kobe: Kobe University, Japan.

Orlitzky, M. (2008). Corporate social performance and financial performance. In Crane, A., Matten, D., McWilliams, A., Moon, J., \& Siegel, D. (Eds), The oxford handbook of corporate social responsibility (pp.113-134). Oxford: Oxford University Press.

Orlitzky, M., Schmidt, F. L., \& Rynes, S. L. (2003). Corporate social and financial performance: A meta-analysis. Organization Studies, 24(3), 403-441.

Porter, M. E. (1991). Towards a dynamic theory of strategy. Strategic Management Journal, 12(52), 95-117. 
Porter, M. E., \& Van der Linde, C. (1995). Toward a new conception of the environment-competitiveness relationship. The journal of economic perspectives, 9(4), 97-118.

Preston, L. E., \& O'bannon, D. P. (1997). The corporate social-financial performance relationship: A typology and analysis. Business \& Society, 36(4), 419-429.

Repetto, R., \& Austin, D. (2000). Pure profit: The financial implications of environmental performance. Washington, DC: World Resources Institute.

Russo, M. V., \& Fouts, P. A. (1997). A resource-based perspective on corporate environmental performance and profitability. Academy of management Journal, 40(3), 534-559.

Schaltegger, S., \& Synnestvedt, T. (2002). The link between 'green' and economic success: Environmental management as the crucial trigger between environmental and economic performance. Journal of environmental management, 65(4), 339-346.

Shrivastava, P., \& Hart, S. (1992). Greening organizations. Proceedings of the Academy of Management, 1992(1), 185-189. Retrieved from http://aom.org/proceedings/

Shrivastava, P. (1995). The role of corporations in achieving ecological sustainability. Academy of management review, 20(4), 936-960.

Smith, R.E. (2011). Defining corporate social responsibility: A systems approach for socially responsible capitalism (Unpublished master's thesis). University of Pennsylvania, Pennsylvania.

Sritharan, V. (2015). Does firm size influence on firms' Profitability? Evidence from listed firms of Sri Lankan Hotels and Travels sector. Research Journal of Finance and Accounting, 6(6), 201-207.

Stanwick, P. A., \& Stanwick, S. D. (1998). The relationship between corporate social performance, and organizational size, financial performance, and environmental performance: An empirical examination. Journal of Business Ethics, 17(2), 195-204.

Stefan, A., \& Paul, L. (2008). Does it pay to be green? A systematic overview. The Academy of Management Perspectives, 22(4), 45-62.

Tanimoto, K. (2013). Corporate social responsibility and management process in Japanese corporations. World Review of Entrepreneurship, Management and Sustainable Development, 9(1), 10-25. 
Trung, D., \& Kumar, S. (2005). Resource use and waste management in Vietnam hotel industry. Journal of Cleaner Production, 13(2), 109-116. Waddock, S. A., \& Graves, S. B. (1997). The corporate social performancefinancial performance link. Strategic Management Journal, 18(4), 303319.

Walley, N., \& Whitehead, B. (1994). It's not easy being green. Harvard Business Review, 72(3), 46-52.

Watson, K.,Klingenberg, B., Polito, T., \& Geurts, T. G. (2004). Impact of environmental management system implementation on financial performance: A comparison of two corporate strategies. Management of Environmental Quality: An International Journal, 15(6), 622-628.

Wood, D. J. (1991). Corporate social performance revisit. The Academy of Management Review, 16(4), 691-718.

Yamada, S. (2006). Corporate social responsibility in Japan. Focused on environmental communication. In Szell, G. (Eds), Corporate social responsibility in the EU and Japan (pp. 341-358). Frankfurt: Peter Lang. 